\title{
Leopard Seals (Hydrurga leptonyx) in New Zealand Waters Predating on Chondrichthyans
}

\author{
Krista van der Linde ${ }^{1,2,3 *}$, Ingrid N. Visser,2,3*, Rick Bout ${ }^{2}$, Chris Lalas ${ }^{5}$, Lara Shepherd ${ }^{6}$, \\ David Hocking ${ }^{7,8}$, Brittany Finucci ${ }^{9}$, Jim Fyfe ${ }^{10}$ and Matthew Pinkerton ${ }^{9}$ \\ ${ }^{1}$ World Wildlife Fund for Nature New Zealand, Wellington, New Zealand, ${ }^{2}$ LeopardSeals.org, Nationwide, New Zealand, \\ ${ }^{3}$ School of Biological Sciences, University of Canterbury, Christchurch, New Zealand, ${ }^{4}$ Orca Research Trust, Tutukaka, \\ New Zealand, ${ }^{5}$ Retired, Dunedin, New Zealand, ${ }^{6}$ Museum of New Zealand Te Papa Tongarewa, Wellington, New Zealand, \\ ${ }^{7}$ Department of Zoology, Tasmanian Museum and Art Gallery, Hobart, TAS, Australia, ${ }^{8}$ School of Biological Sciences, \\ Monash University, Clayton, VIC, Australia, ${ }^{9}$ National Institute of Water and Atmospheric Research, Wellington, \\ New Zealand, ${ }^{10}$ Department of Conservation, Dunedin, New Zealand
}

OPEN ACCESS

Edited by:

Oliver Nicholas Shipley, University of New Mexico,

United States

Reviewed by:

Aldo S. Pacheco,

National University of San Marcos,

Peru

David Ainley,

H. T. Harvey \& Associates,

United States

*Correspondence:

Krista van der Linde kvanderlinde@wwf.org.nz

Ingrid N. Visser

ingrid@orca.org.nz

Specialty section: This article was submitted to

Marine Megafauna,

a section of the journal

Frontiers in Marine Science

Received: 15 October 2021 Accepted: 05 November 2021 Published: 16 December 2021

Citation: van der Linde K, Visser IN, Bout $R$, Lalas $C$, Shepherd L, Hocking $D$, Finucci B, Fyfe $J$ and Pinkerton $M$ (2021) Leopard Seals (Hydrurga leptonyx) in New Zealand Waters

Predating on Chondrichthyans.

Front. Mar. Sci. 8:795358. doi: 10.3389/fmars.2021.795358
Leopard seals (Hydrurga leptonyx) are top-order predators that prey on a wide variety of species including crustaceans, cephalopods, fishes, birds, and pinnipeds. While multiple diet studies have been conducted worldwide, there are no previous accounts of leopard seals predating on chondrichthyans. As part of a wider study on the diet of leopard seals in New Zealand (NZ) waters, researchers and citizen scientists recorded 39 observations of predation and collected 127 scats (166 total records) between 1942 and 2019. Predation on chondrichthyans was detected in $23.1 \%(n=9)$ of observations of predation and $7.1 \%(n=9)$ of scats (the latter via morphological examination and DNA sequencing). From both observations of predations and scats, three chondrichthyan species or genus were identified; elephantfish (Callorhinchus milii), ghost sharks (Hydrolagus spp.) and spiny dogfish (Squalus acanthias). While this is the first published record of leopard seals feeding on chondrichthyans, the relatively high frequency of occurrence within our NZ records, and that certain individuals appeared to target this type of prey, indicates that these species could constitute a substantial, or important, part of the diet for some leopard seals in this region. As chondrichthyans form an important part of the NZ marine ecosystems, our recognition of an additional top-order predator of these species contributes to understanding the overall health of, and future impacts of predators on, the wider NZ marine ecosystem.

Keywords: chondrichthyans, diet, elephantfish, ghost shark, leopard seal, predation, scat, spiny dogfish

\section{INTRODUCTION}

Leopard seals (Hydrurga leptonyx) are large, top-order predators that have a typical circumpolar distribution and are locally abundant between $50^{\circ}$ and $80^{\circ} \mathrm{S}$ (Riedman, 1990; Casaux et al., 2009). In addition to this distribution, some individuals disperse further northwards to the continents and islands abutting the Southern Ocean (Hupman et al., 2020).

The predation behavior of high trophic level predators, including pinnipeds, has the ability to alter marine ecosystems through direct (e.g., predation) and indirect (e.g., predation on shared prey resources) pathways (Rosenblatt et al., 2013; Kiszka et al., 2015). While limited studies to date have discussed dietary competition between leopard seals and other species [species discussed 
include Adélie penguins (Pygoscelis adeliae) and crabeater seals (Lobodon carcinophagus) (Siniff and Stone, 1985)], there is the potential that leopard seals can affect marine ecosystems through competition with sympatric mesopredators (e.g., Cupples et al., 2011) or perceived predation risk which can reduce mesopredator fitness (e.g., Gigliotti et al., 2020). Despite these potential ecosystem effects, even today we still have a "poor understanding of [leopard seal] foraging ecology" (Krause et al., 2020).

We do know, however, that leopard seals are excellent generalist predators with a suite of highly specialized adaptations. They are highly maneuverable swimmers (Hocking et al., 2021) in part due to their comparatively large wing-like forelimb flippers. Their agility, along with their relatively large size and gape enable them to target sizable prey species across their wide circumpolar distribution (Rogers, 2018). But rather than being restricted to only large prey, their unique dual-functioning dentition is well suited to both sieving smaller prey from the water and processing larger prey (Hamilton, 1939; Kooyman, 1981; Hocking et al., 2013; Robbins et al., 2019). As such, they take a wide selection of prey, ranging from Antarctic krill (Euphausia superba), cephlapods and fishes, to seabirds and other pinnipeds (Siniff and Stone, 1985; Hall-Aspland and Rogers, 2004; Krause and Rogers, 2019). In addition, the composition of their diet is known to vary with both season (Laws, 1984; Krause et al., 2020) and location (Laws, 1984). Rogers (2018) proposed that some leopard seals (presumed by the author to be juvenile animals) moved north, beyond the pack ice, during austral winter when prey species become limited, and competition is high. Although leopard seals have been documented in New Zealand (NZ) since at least the 12th Century and more recently year-round (Hupman et al., 2020), very little has been published regarding their prey in this region, with only seven species of prey identified to species level, all of which were seabirds (Guy, 1947; Johnston and Mawson, 1953; Bailey and Sorensen, 1962; Horning and Fenwick, 1978; Duffy and Brown, 1994; McKinlay et al., 2014).

A number of pinniped species are known to feed on chondrichthyans (Martin, 2004; Allen and Huveneers, 2005; Fallows et al., 2015), which include the subclasses Holocephali (chimeras) (Weigmann, 2016) and Elasmobranchii (sharks, skates and rays). In NZ waters, NZ fur seals (Arctocephalus forsteri) frequently consume chondrichthyans, with chimeras specifically, elephantfish - being particularly important prey items (Emami-Khoyi et al., 2016). In addition, for NZ sea lions (Phocarctos hookeri), skates are important prey, specifically rough skates (Dipturus nasuta) (Lalas, 1997; Lalas et al., 2007; Lalas and Webster, 2014; Roberts and Lalas, 2015). A number of authors have described leopard seals in Australian waters being wounded by stingray barbs (e.g., Elliot, 1982; Warneke, 1995), specifically from the sparsely spotted stingaree (Urolophus paucimaculatus) (e.g., King, 1983) and Dasyatis sp. (e.g., Rounsevell and Pemberton, 1994).

One of the key focus areas of the research conducted by LeopardSeals.org ${ }^{1}$ is to identify prey species targeted by leopard seals within NZ waters, via observations of predation

\footnotetext{
${ }^{1}$ LeopardSeals.org is a not-for-profit organization dedicated to research, conservation and education on leopard seals in New Zealand.
}

and through the analysis of scats (morphological and DNA sequencing). Herein we describe the records of leopard seals predating chondrichthyans in NZ, which also appear to be the first records worldwide. We examined observations of predation to ascertain the number of intact prey and embedded spines (including injuries).

\section{MATERIALS AND METHODS}

\section{Definitions}

For this study, data was divided into two main categories: (1) 'observations of predation', which included visual observations and evidence (photographs or video) of leopard seals consuming or caching prey (either partially consumed or intact items, or, of prey embedded in their bodies) and (2) 'scat remains' (hereafter referred to as 'scats') which included non-fecal material that was not digested (e.g., prey hard and soft parts such as feathers, scales, bones, as well as fishing line, parasites, nematodes etc.) recovered from scats.

Within this study we use the terms chimaera(s)/chimaeroid(s)/chimaeriform(s) to refer to chondrichthyans in the Subclass Holocephali, order Chimaeriformes, which includes both elephantfish (Family Callorhinchidae, Genus Callorhinchus, also known as plownose chimeras) and ghost sharks (Family Chimaeridae, Genus Hydrolagus, also known as, rat fish, spookfish, or rabbit fish). We use the term 'unidentified Chimaeriform' when referring to an unidentified genus and/or species in the Order Chimaeriformes.

\section{Data Collection and Examination Locations and Regions}

LeopardSeals.org collected published and unpublished records of leopard seals from several geographically independent NZ 'locations' (Figure 1). Each location was categorized into a 'region' based on the NZ Government designation (i.e., this is the same system used for the Department of Conservation Marine Mammal Database). North to south, the North Island regions were; Northland, Auckland, Waikato, Bay of Plenty, Whanganui, East Coast/Hawke's Bay and Wellington, while the South Island regions were; West Coast, Nelson/Marlborough, Canterbury, Otago, Southland. In addition to mainland NZ, we also included the regions and oceanic areas of NZ's Offshore Islands (Auckland, Campbell, Chatham, Snares and Stewart Islands) as well as the South Pacific Ocean within the NZ Exclusive Economic Zone (Department of Conservation, 1990; Hupman et al., 2020).

\section{Published and Unpublished Records}

The published literature was examined for evidence of leopard seal predation or leopard seal scats indicating feeding on chondrichthyans in NZ waters. Unpublished records of leopard seal observations of predation or scats indicating evidence of feeding on chondrichthyans were collected by LeopardSeals.org. These unpublished records came from either opportunistic observations/collections by LeopardSeals.org researchers/affiliates (hereafter referred to as LeopardSeals.org) or citizen scientists. 


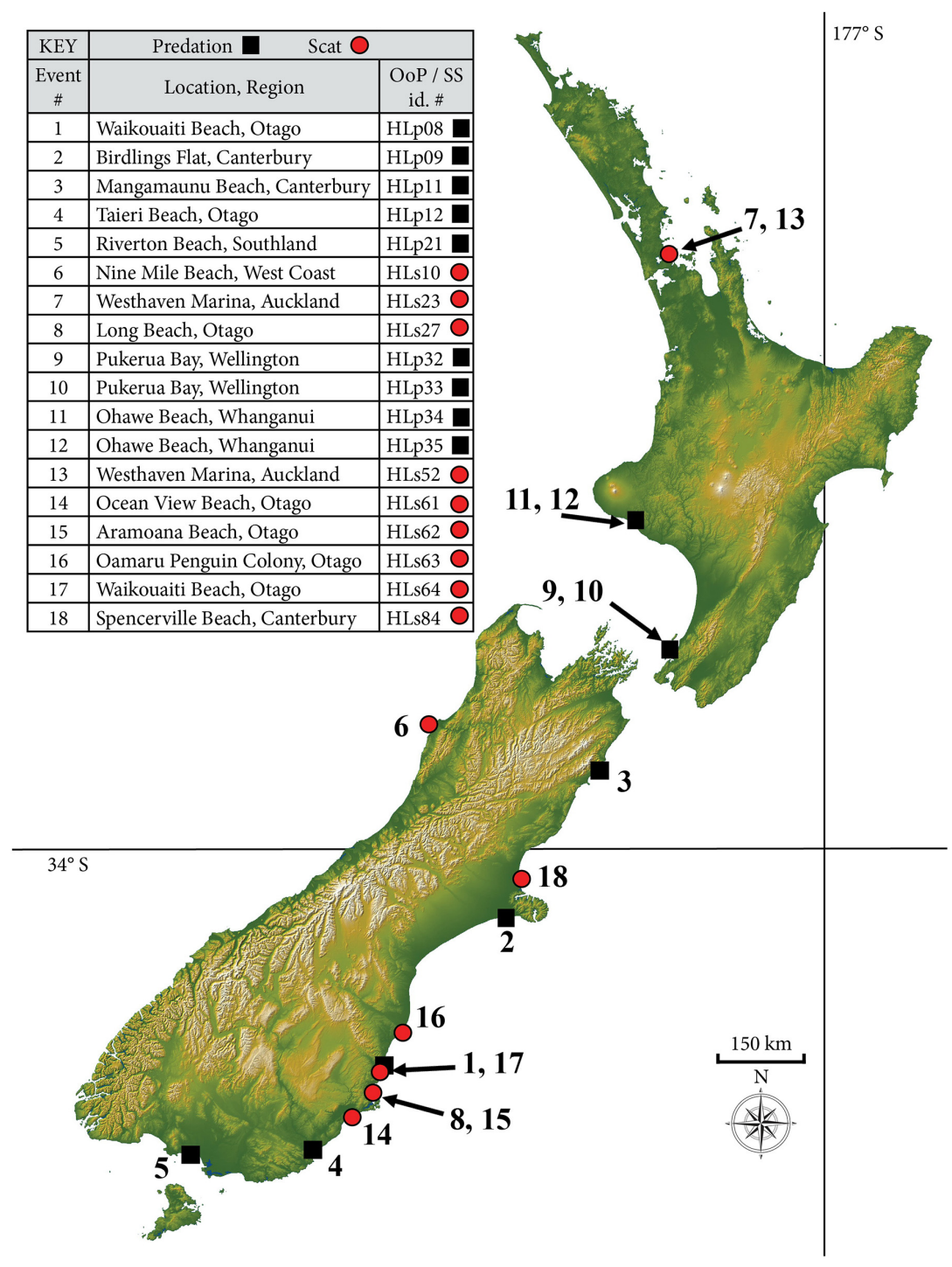

FIGURE 1 | Distribution of 18 leopard seal (Hydrurga leptonyx) predation events on chondrichthyans in New Zealand, indicating observations of predation (OoP, black squares) and scats (SS, red circles), noting that some locations contain more than one event. See methods for definition of regions. id. \# is event number.

Citizen scientist observations/collections were enabled via leopard seal reporting systems including a tollfree phone number 0800 LEOPARD (0800 5367273), website $^{2}$ (which includes a sightings submission page), email (info@LeopardSeals.org) and social media channels (Leopard Seals NZ). Additionally, LeopardSeals.org observations/collections were enabled via: (1) opportunistic observations; (2) frequent checking of known haul-out sites via established 'sighting networks', and/or; (3) continuous monitoring of selected haul-out sites via trail cameras [see Supplementary Material 1 (SM1) for further details].

Opportunistic observations by LeopardSeals.org involving photography used DSLR cameras including a Canon 700D DSLR camera fitted with a $18-135 \mathrm{~mm}$ lens, a Nikon 7100 DSLR camera

${ }^{2}$ www.leopardseals.org fitted with a 70-400 mm lens and a Cannon EOS 5D Mark III fitted with an 80-200 mm lens.

\section{Observations of Predation}

Observations of leopard seal predation were recorded between July 2007 and May 2019. Each observation of predation was referred to as an 'event' and given a unique identification number which included the initials HL (for Hydrurga leptonyx) followed by a 'p' (for predation) and a chronological number (e.g., HLp01). If multiple observations of one predation were reported, only one unique identification number was assigned to the collective data set for that event.

For observations of predation, photographs and/or videos were taken for identification of the leopard seal and identification of prey, with the latter completed via visual inspection and by comparison with fish identification guides (Roberts et al., 2015; 
McMillan et al., 2019). Where possible, remains or abandoned prey/items were collected from the field to confirm species, and measurements or estimations of size were completed. Where leopard seals had been observed alive, later died and were subsequently necropsied, any findings of predation were still considered observations of predation.

\section{Scats}

Leopard seal scats were collected between May 2016 and October 2019. We use the term 'event' to describe a scat collection from a particular location. When possible, scats were photographed in situ prior to collection, with a ruler adjacent. Each scat was bagged (see Supplementary Material 1 for further information) and labeled with the date (yyyymmdd), time $(24 \mathrm{~h})$ and location of collection (i.e., the specific site, location, region and latitude/longitude), along with collector(s) name(s) and NZ Leopard Seal Catalogue (NZLSC) number and/or the 'nickname' of the individual (if the animal was cataloged in the NZLSC, see details below). Each scat was also given a unique identification number which included the initials HL followed by an 's' (for scat) and a chronological number (e.g., HLs01). The scats were then frozen $\left(-20^{\circ} \mathrm{C}\right)$ until processed.

Upon defrosting, photographs were taken of the scat(s). The scats were then processed using methods adapted from HallAspland and Rogers (2004). In summary, in order to separate the non-fecal from fecal materials, scats was placed in a sieve (with the largest mesh size of $1 \mathrm{~mm}$ ), washed with water, agitated and broken up and thoroughly rinsed until only the non-fecal material remained. Non-fecal materials were then extracted onto a tray using sterilized tweezers, sorted and grouped by material type (e.g., bone, feather, miscellaneous, scales, vegetation etc.) for further examination. Material types were then separated by potentially different species where possible (e.g., feathers from two different species were separated from each other).

Photographs of each material/possible species type were taken post sorting. Each material/possible species type was then bagged separately and stored frozen $\left(-20^{\circ} \mathrm{C}\right)$. Non-fecal materials were not fixed in formalin or ethanol in an effort to allow each material/possible species type to be processed in different ways for identification (e.g., some DNA sequencing techniques require that they are not fixed in ethanol/formalin).

\section{Prey Identification}

All non-fecal materials that represented prey items were assessed by experts for species identification. Prey identification experts also confirmed the certainty of species identification (which was classified as certain or possible) or if the species was not identifiable. The location where the event occurred was not revealed to the prey identification experts, to avoid potential biases formed by existing knowledge of species biogeographical ranges.

Non-fecal materials from prey items were examined for morphological identification and prey species were identified to the lowest taxonomic level based on typical species-specific criteria (see Supplementary Material 1 for further details). Identification of prey taxa from diagnostic remains in scats followed Lalas and Webster (2014) and involved comparisons with an extensive collection of diagnostic remains held by Lalas (unpublished data) and comparison to prey hard parts in published literature (e.g., Compagno, 1988; McEachran and Konstantinou, 1996; Leach, 1997; Gravendeel et al., 2002; Last and Stevens, 2009). The key hard parts indicative of chondrichthyan remains in scats were; opaque (white or yellow) vertebra that lacked fused spines or arches, calcified tooth plates, enameloid teeth and calcified dermal denticles (including thorns), calcified dorsal fin spine sheaths, jaws and girdles (see Supplementary Material 2 for some examples). Chondrichthyan prey remains were retained and stored dry in sealable plastic bags.

DNA sequencing of non-fecal materials was conducted to confirm identity of species (see Supplementary Material 1 for further details). DNA was extracted from bones using a modified DNeasy blood and tissue kit (Qiagen) as described in Shepherd and Campbell (2021), with the exception that the extractions were not performed in an ancient DNA laboratory. The mitochondrial $16 \mathrm{~S}$ rRNA gene was amplified using the 16Sarl and 16Sbrh primers (Simon et al., 1994). PCR amplifications were performed in $12 \mu \mathrm{l}$ volumes containing $1 \times$ MyTaq mix (Bioline, Australia), $0.3 \mathrm{M}$ of bovine serum albumin (BSA) and $0.5 \mu \mathrm{M}$ of each primer. PCR amplification involved an initial denaturation of $98^{\circ} \mathrm{C}$ for $1 \mathrm{~min}$ then 35 cycles of $98^{\circ} \mathrm{C}$ for $20 \mathrm{~s}, 55^{\circ} \mathrm{C}$ for $20 \mathrm{~s}$ and $72^{\circ} \mathrm{C}$ for $30 \mathrm{~s}$, followed by a final extension of $72^{\circ} \mathrm{C}$ for $5 \mathrm{~min}$. PCR products were visualized on a $1 \%$ agarose gel to confirm amplification. Successful amplifications were purified by digestion with $0.5 \mathrm{U}$ shrimp alkaline phosphatase (rSAP; New England Biolabs, MA, United States) and $2.5 \mathrm{U}$ exonuclease I (Exo I; New England Biolabs, MA, United States) at $37^{\circ} \mathrm{C}$ for $15 \mathrm{~min}$, followed by inactivation of the enzymes by $15 \mathrm{~min}$ at $80^{\circ} \mathrm{C}$. DNA sequencing was performed by capillary separation at Macrogen (Seoul, South Korea).

Sequences were edited in Sequencer 5.4.6 (Gene Codes Corporation). Taxonomic assignment of sequences was performed with a MEGABLAST search of the online database GenBank $k^{3}$. Sequences were assigned to a species if they shared more than $98 \%$ similarity across the entire length of sequence, following Valentini et al. (2009). However, sequences that matched more than one taxon equally were assigned to the higher taxonomic level (genus or family) that included all of the matching species. These raw assignments were checked following the method of Seersholm et al. (2018): each taxonomic node was examined and checked against records of species that are known to be present in NZ and the availability of reference sequences of similar species known from NZ. Assignments were upgraded to species level when lower taxonomic nodes only contained a single NZ species. Similarly, assignments were downgraded to genus level where sequences from similar species within the same genus from NZ were absent from GenBank.

\section{Classification of Individual Leopard Seals}

For every leopard seal sighting in this study, we recorded the date and location. In addition, we recorded the age class, sex, if tooth wear occurred and body condition score (see Supplementary Material 1 for further information). We also attempted to obtain

\footnotetext{
${ }^{3}$ https://blast.ncbi.nlm.nih.gov/Blast.cgi
} 
photo-identification (photo-id) of the individual. All individuals which had photographs that met specific photo-quality and cataloging criteria were entered into the NZLSC and the seal was assigned a catalog number and 'nickname' (see Supplementary Material 1 for further details).

\section{Data Analysis}

This paper specifically examines leopard seals feeding on chondrichthyans ${ }^{4}$. We examined the number of times chondrichthyan species were identified by: (a) austral seasons ${ }^{5}$, [i.e., spring (September to November), summer (December to February), autumn (March to May) and winter (June to August)]; (b) region (see Supplementary Material 1 for further details) and (c) individual characteristics (age class, sex, tooth wear, and body condition). We present detailed accounts of observations of predation (intact prey and embedded dorsal fin spines) and an overview of the results from the scats.

\section{RESULTS}

\section{Identification of Chondrichthyans}

We collated a total of 166 records of leopard seal predation on a range of prey types. Collectively, $48.8 \%(n=81)$ were from citizen scientists and $51.2 \%(n=85)$ were from LeopardSeals.org. Of the 166 records of leopard seal predation, 39 were from observations of predation whilst 127 were from scats. Specifically, of the 39 observations of predation, $82.1 \%(n=32)$ were made by citizen scientists and $17.9 \%(n=7)$ were made by LeopardSeals.org. Of the 127 scats, $38.6 \%(n=49)$ were collected by citizen scientists and $61.4 \%(n=78)$ were collected by LeopardSeals.org. Of the 39 observations of predation, $23.1 \%(n=9)$ documented leopard seals feeding on chondrichthyans. Of the 127 scats, $7.1 \%$ $(n=9)$ contained chondrichthyan remains. Three species of chondrichthyans were identified; elephantfish $(n=1)$, ghost shark $(n=1)$, spiny dogfish $(n=10)$. In addition, 6 records were unidentified chimaeriformes (Table 1).

\section{Seasonal Occurrence}

Leopard seals predated on chondrichthyans during all austral seasons, with the highest detections in spring $(19 \%, n=11)$

${ }^{4}$ Additional prey types are published elsewhere.

${ }^{5}$ http://www.bom.gov.au/climate/glossary/seasons.shtml and winter $(12.8 \%, n=5)$ (Table 1). When examining seasonal leopard seal predation via species, elephantfish were detected in winter $(n=1)$, ghost sharks in spring $(n=1)$, spiny dogfish in all seasons (spring, $n=6$; summer, $n=1$; autumn, $n=1$; winter, $n=2)$ and unidentified chimaeriformes in spring $(n=4)$ and winter $(n=2)$ (Table 1).

\section{Regional Occurrence}

Leopard seals predated on chondrichthyans in seven NZ regions (Figure 1 and Table 2). Of the 18 chondrichthyan predation records, only $4.4 \%(n=6)$ of the North Island records contained chondrichthyan remains, in contrast to $42.9 \%(n=12)$ of the South Island records.

\section{Individual Characteristics}

Of the 18 observations of predation and scats where leopard seals were documented predating on chondrichthyans, we confirmed that 10 individuals were involved (Table 3). Of those leopard seals where age class could be determined $(n=17)$, chondrichthyan predation was observed in adults $(n=11)$ and juveniles $(n=6)$ (Table 3). Of those leopard seals where sex could be determined $(n=14)$, chondrichthyan predation was observed in males $(n=3)$ and females $(n=11)$ (Table 3$)$. For those leopard seals where tooth wear could be assessed $(n=11)$, wear was only identified in one animal, and the remaining individuals $(n=10)$ showed no wear (Table 3). The one individual that did show tooth wear was an adult female (NZLSC HLNZ-P068, Autahi) who was found alive but subsequently died and a necropsy was performed. The findings included that she had major periodontal disease, with the lower molars in particular having their roots exposed and loose. The upper left canine was cracked and had the pulp exposed whilst the upper right canine was fractured at the gum level and abscessed pulp was exposed. The incisors had gum disease and were loose. For those leopard seals where body condition could be assessed $(n=17)$, the condition was either excellent $(n=12)$, $\operatorname{good}(n=4)$, or fair $(n=1)$ (Table 3$)$.

\section{Detailed Accounts} Observations of Predation

Within the nine observations of leopard seal predation on chondrichthyans, 33.3\% $(n=3)$ included intact prey items (Table 4 and Figure 2). Species detected were elephantfish,

TABLE 1 | Seasonal distribution of chondrichthyan predation records from leopard seals (Hydrurga leptonyx) in New Zealand.

\begin{tabular}{|c|c|c|c|c|c|c|c|}
\hline \multirow[t]{2}{*}{ Season } & \multirow{2}{*}{$\begin{array}{c}\text { All prey species } \\
\begin{array}{c}\text { \# Observations of predation } \\
\text { and scats combined }\end{array}\end{array}$} & \multicolumn{6}{|c|}{ Chondrichthyans as prey } \\
\hline & & $\begin{array}{c}\text { Elephantfish } \\
\text { (Callorhinchus milii) }\end{array}$ & $\begin{array}{c}\text { Ghost sharks } \\
\text { (Hydrolagus spp.) }\end{array}$ & $\begin{array}{c}\text { Spiny dogfish } \\
\text { (Squalus acanthias) }\end{array}$ & $\begin{array}{l}\text { Unidentified } \\
\text { chimaeriform }\end{array}$ & $\begin{array}{l}\text { \# Detections } \\
\text { (total) }\end{array}$ & $\begin{array}{c}\% \text { Detections } \\
\text { (total) }\end{array}$ \\
\hline Spring & 58 & - & 1 & 6 & 4 & 11 & 19 \\
\hline Summer & 14 & - & - & 1 & - & 1 & 7.1 \\
\hline Autumn & 55 & - & - & 1 & - & 1 & 1.8 \\
\hline
\end{tabular}

Seasons refer to austral seasons (see methods for further details). 
TABLE 2 | Regional distribution of the 18 chondrichthyan predation records from leopard seals (Hydrurga leptonyx) in New Zealand.

\begin{tabular}{|c|c|c|c|c|}
\hline \multirow[t]{2}{*}{ Island } & \multirow[t]{2}{*}{ Region(from north to south) } & \multirow{2}{*}{$\frac{\text { All prey species }}{\text { \# Observations of predation and scats combined }}$} & \multicolumn{2}{|c|}{ Chondrichthyans as prey } \\
\hline & & & \# Detections & $\%$ Detections \\
\hline \multirow[t]{7}{*}{ North Island } & Northland & 68 & 0 & 0 \\
\hline & Auckland & 61 & 2 & 3.3 \\
\hline & Waikato & 0 & 0 & 0 \\
\hline & Bay of Plenty & 1 & 0 & 0 \\
\hline & Whanganui & 2 & 2 & 100 \\
\hline & East Coast/Hawke's Bay & 0 & 0 & 0 \\
\hline & Wellington & 4 & 2 & 50 \\
\hline Total North Island & - & 136 & 6 & 4.4 \\
\hline \multirow[t]{5}{*}{ South Island } & West Coast & 4 & 1 & 25 \\
\hline & Nelson/Marlborough & 2 & 0 & 0 \\
\hline & Canterbury & 6 & 3 & 50 \\
\hline & Otago & 13 & 7 & 53.8 \\
\hline & Southland & 3 & 1 & 33.3 \\
\hline Total South Island & - & 28 & 12 & 42.9 \\
\hline Offshore & Sub-Antarctic Islands & 2 & 0 & 0 \\
\hline Total NZ & - & 166 & 18 & 10.8 \\
\hline
\end{tabular}

See methods for definition of regions.

TABLE 3 | Individual assessment of leopard seals (Hydrurga leptonyx) who have been documented predating on chondrichthyans in New Zealand.

\begin{tabular}{|c|c|c|c|c|c|c|}
\hline OoP/SS id. \# & Age class & Sex & NZLSC \# (Name) & $\begin{array}{l}\text { Tooth } \\
\text { wear }\end{array}$ & $\begin{array}{l}\text { Body } \\
\text { condition }\end{array}$ & Species \\
\hline HLp08 & Adult & Female & HLNZ-P068 (Autahi) & Yes & Fair & Unidentified chimaeriform \\
\hline HLp09 & Juvenile & $\mathrm{NK}^{1}$ & HLNZ-P043 & No & Excellent & Unidentified chimaeriform \\
\hline HLp11 & Adult & $\mathrm{NK}^{1}$ & $\mathrm{NK}^{2}$ & No & Excellent & $\begin{array}{l}\text { Ghost shark, presumably dark ghostshark } \\
\text { (Hydrolagus novaezealandiae) }\end{array}$ \\
\hline HLp12 & Adult & Male & HLNZ-030 & No & Excellent & Unidentified chimaeriform \\
\hline HLp21 & Adult & Female & HLNZ-P057 & No & Excellent & Elephantfish (Callorhinchus milii) \\
\hline HLs10 & Juvenile & Male & HLNZ-009 (Hatea) & No & Excellent & Spiny dogfish (Squalus acanthias) \\
\hline HLs23 & Adult & Female & HLNZ-001 (Owha) & $\mathrm{NK}^{4}$ & Excellent & Spiny dogfish \\
\hline HLs27 & $\mathrm{NK}^{3}$ & $\mathrm{NK}^{3}$ & $\mathrm{NK}^{3}$ & $\mathrm{NK}^{3}$ & $\mathrm{NK}^{3}$ & Spiny dogfish \\
\hline HLp32 & Juvenile & Female & HLNZ-0011 & No & Good & Unidentified chimaeriform \\
\hline HLp33 & Juvenile & Female & HLNZ-0011 & No & Good & Unidentified chimaeriform \\
\hline HLp34 & Juvenile & Female & HLNZ-0011 & No & Good & Spiny dogfish \\
\hline HLp35 & Juvenile & Female & HLNZ-0011 & No & Good & Unidentified chimaeriform \\
\hline HLs52 & Adult & Female & HLNZ-001 (Owha) & $\mathrm{NK}^{4}$ & Excellent & Spiny dogfish \\
\hline HLs61 & Adult & Female & HLNZ-092 & No & Excellent & Spiny dogfish \\
\hline HLs62 & Adult & Male & $\mathrm{NK}^{2}$ & $\mathrm{NK}^{4}$ & Excellent & Spiny dogfish \\
\hline HLs63 & Adult & Female & HLNZ-093 & $\mathrm{NK}^{4}$ & Excellent & Spiny dogfish \\
\hline HLs64 & Adult & Female & HLNZ-092 & $\mathrm{NK}^{4}$ & Excellent & Spiny dogfish \\
\hline HLs84 & Adult & $\mathrm{NK}^{1}$ & HLNZ-P099 & $\mathrm{NK}^{4}$ & Excellent & Spiny dogfish \\
\hline
\end{tabular}

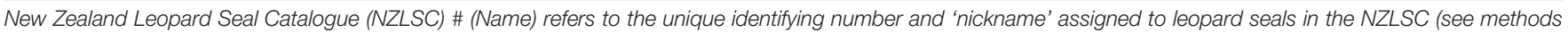
for further details).

OoP/SS id. \#, observations of predation/seal scat identifiation number. NK, not known.

${ }^{1}$ Photographs provided were not sufficient for determining sex.

${ }^{2}$ Photographs provided were not sufficient for photo-identification and therefore this seal could not be entered into or matched to the NZLSC.

${ }^{3}$ Photographs were not provided and therefore this seal's age class, sex, body condition and/or tooth wear could not be determined.

${ }^{4}$ Photographs provided did not show this seals teeth.

ghost shark (presumably dark ghostshark, Hydrolagus novaezealandiae) and spiny dogfish (Table 4).

Within the nine observations of leopard seal predation on chondrichthyans, 66.7\% $(n=6)$ included embedded spines (Table 5 and Figure 3), all from unidentified chimaeriforms (Table 5). There were a total of 12 spines and the number of spines in any one event ranged from 1 to 3 (Figure 3).
However, we note that some spines, particularly if broken off (like two of the three visible in Figure 3C), may have been undetectable due to the pelt of the leopard seal, particularly when the pelt was dry. Furthermore, we did not always have (a) high quality photographs or (b) photographs showing both sides of the head and therefore, again, embedded spines may not have been detected. We did however document sequential 
TABLE 4 | Observations of leopard seals (Hydrurga leptonyx) predating on chondrichthyans in New Zealand waters, where the prey was found intact.

\begin{tabular}{|c|c|c|c|c|c|c|}
\hline $\begin{array}{l}\text { Date } \\
\text { (yyyymmdd) }\end{array}$ & Location & Age class, sex & NZLSC \# (Name) & OoP id. \# & Species & Figure \\
\hline 20150903 & $\begin{array}{l}\text { Mangamaunu Beach, } \\
\text { Hapuku, Canterbury }\end{array}$ & Adult, $\mathrm{NK}^{1}$ & $\mathrm{NK}^{2}$ & HLp11 & $\begin{array}{l}\text { Ghost shark, presumably dark ghostshark } \\
\text { (Hydrolagus novaezealandiae) }\end{array}$ & $2 \mathrm{~A}$ \\
\hline 20170809 & $\begin{array}{l}\text { Riverton Beach, } \\
\text { Riverton, Southland }\end{array}$ & Adult, Female & HLNZ-P057 & HLp21 & $\begin{array}{l}\text { Elephantfish } \\
\text { (Callorhinchus milii) }\end{array}$ & $2 \mathrm{~B}$ \\
\hline 20180821 & $\begin{array}{l}\text { Ohawe Beach, Ohawe, } \\
\text { Whanganui }\end{array}$ & Juvenile, Female & HLNZ-P111 & HLp34 & $\begin{array}{l}\text { Spiny dogfish } \\
\text { (Squalus acanthias) }\end{array}$ & $2 \mathrm{C}$ \\
\hline
\end{tabular}

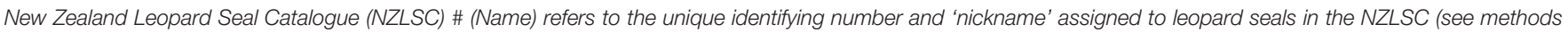
for further details).

NK, not known; OoP id \#, observations of predation see Table 4 for details, identification number.

${ }^{1}$ Photographs provided were not sufficient for determining sex.

${ }^{2}$ Photographs provided were not sufficient for photo-identification and therefore this seal could not be entered into or matched to the NZLSC.

spine embedment, where HLNZ-P111 - a juvenile female - had seven spines embedded on the right side of her face during three different events (black circles in Figures 3D-F) over a 25-day period.

\section{Injuries by Chondrichthyans}

Within the six events of embedded spines from unidentified chimaeriforms (Figure 3) we also noted puncture injuries (i.e., likely from spines that were no longer present, see white circles in Figures 3B-F). One leopard seal, HLNZ-P111 was documented with seven of these wounds on the right side of her face (Figure 3D), of which five were still visible 7 days later (Figure 3F). These were in addition to the seven spines embedded on the right side of her face (black circles in Figures 3D-F), resulting in a minimum of 14 wounds from chondrichthyans.

\section{Scats}

Nine scats showed evidence of leopard seals predating on chondrichthyans (see examples in Supplementary Material 2), all of which were of spiny dogfish (Table 6). Of those nine scats, predation on chondrichthyans was detected three times based on morphological examination alone, as compared to six times based on morphological examination and DNA sequencing (Table 6).

Seven of the nine scats with chondrichthyan remains included skeletal remains reliably identified to the spiny dogfish (Supplementary Material 1). The other two contained only vertebrae that resembled those of spiny dogfish therefore they could not be identified morphologically to species level (Supplementary Material 2).

\section{Leopard Seals Targeting Chondrichthyans}

At least 10 individual leopard seals were identified that predate on chondrichthyans. Of these, both HLNZ-001 and HLNZ092 were found predating on spiny dogfish on two occasions (Table 6), whereas HLNZ-P111 was found to predate on both chimeras $(n=3)$ and spiny dogfish $(n=1)$ (Tables 4, 6). See the section above regarding the number of spines and injuries on HLNZ-P111.
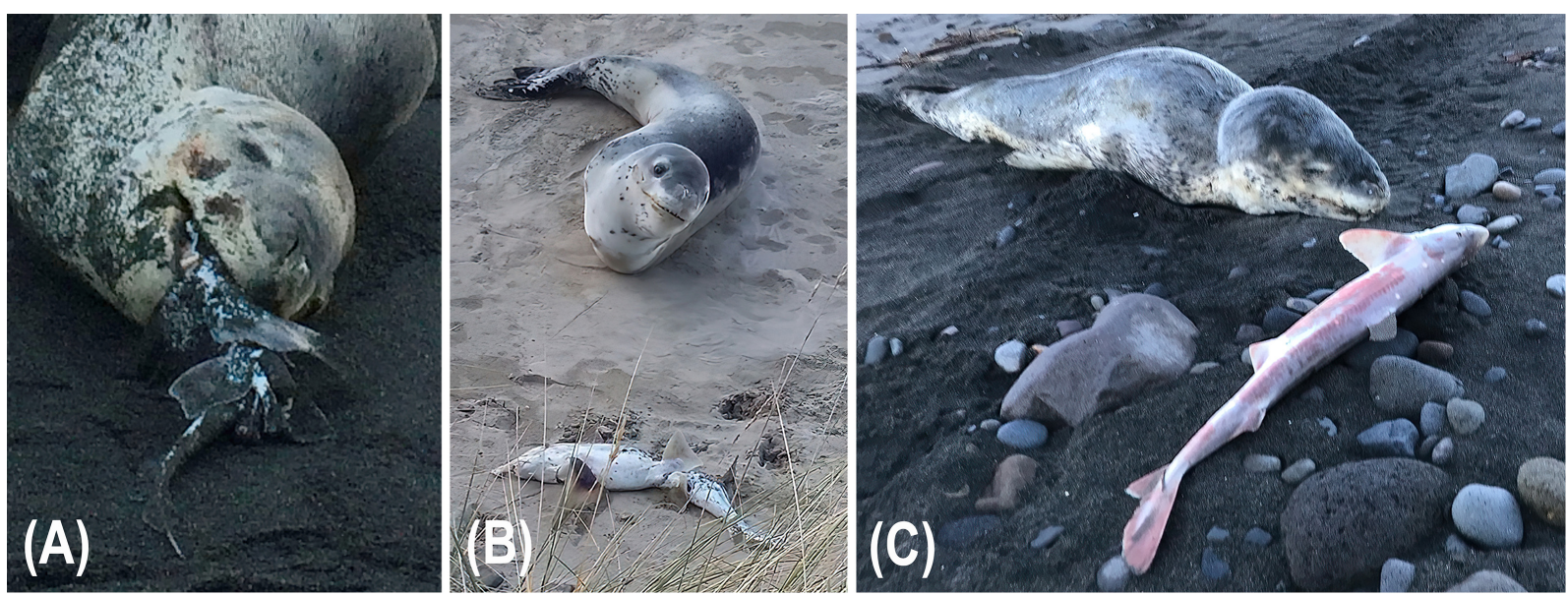

FIGURE 2 | Leopard seal (Hydrurga leptonyx) observations of predation in New Zealand, involving intact prey items: (A) unidentified adult of unknown sex, sighted 3 September 2015, at Mangamaunu Beach, Hapuku, Canterbury, with a partially ingested ghost shark, photograph Sue Parsons; (B) adult female HLNZ-P057, sighted 9 August 2017, at Riverton Beach, Riverton, Southland, with an elephantfish (Callorhinchus milii) laying adjacent, photograph Anita Spencer; (C) juvenile female HLNZ-P111, sighted 21 August 2018, at Ohawe Beach, Whanganui, with spiny dogfish (Squalus acanthias) laying adjacent, photograph Karen Pratt. 
TABLE 5 | Observations of leopard seals (Hydrurga leptonyx) predating on chondrichthyans in New Zealand waters, where embedded spines were found.

\begin{tabular}{|c|c|c|c|c|c|c|}
\hline Date (yyyymmdd) & Location & Age class, sex & NZLSC \# (Name) & OoP id. \# & Species & Figure \\
\hline 20091126 & Waikouaiti Beach, Otago & Adult, Female & HLNZ-P068 (Autahi) & HLp08 & Unidentified chimaeriform & $3 A$ \\
\hline 20101015 & Birdlings Flat, Canterbury & Juvenile, $\mathrm{NK}^{1}$ & HLNZ-P043 & HLp09 & Unidentified chimaeriform & $3 B$ \\
\hline 20150920 & Taieri Beach, Otago & Adult, Male & HLNZ-030 & HLp12 & Unidentified chimaeriform & $3 C$ \\
\hline 20180815 & Pukerua Bay, Wellington & Juvenile, Female & HLNZ-P111 & HLp32 & Unidentified chimaeriform & $3 \mathrm{D}$ \\
\hline 20180818 & Pukerua Bay, Wellington & Juvenile, Female & HLNZ-P111 & HLp33 & Unidentified chimaeriform & $3 \mathrm{E}$ \\
\hline 20180821 & Ohawe Beach, Ohawe, Whanganui & Juvenile, Female & HLNZ-P111 & HLp34 & Unidentified chimaeriform & $3 F$ \\
\hline
\end{tabular}

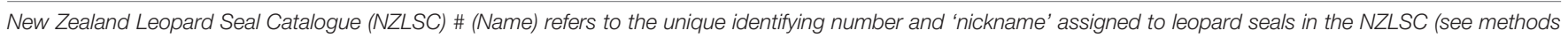
for further details).

OoP id. \#, observations of predation identification number.

${ }^{1}$ Photographs provided were not sufficient for determining sex.
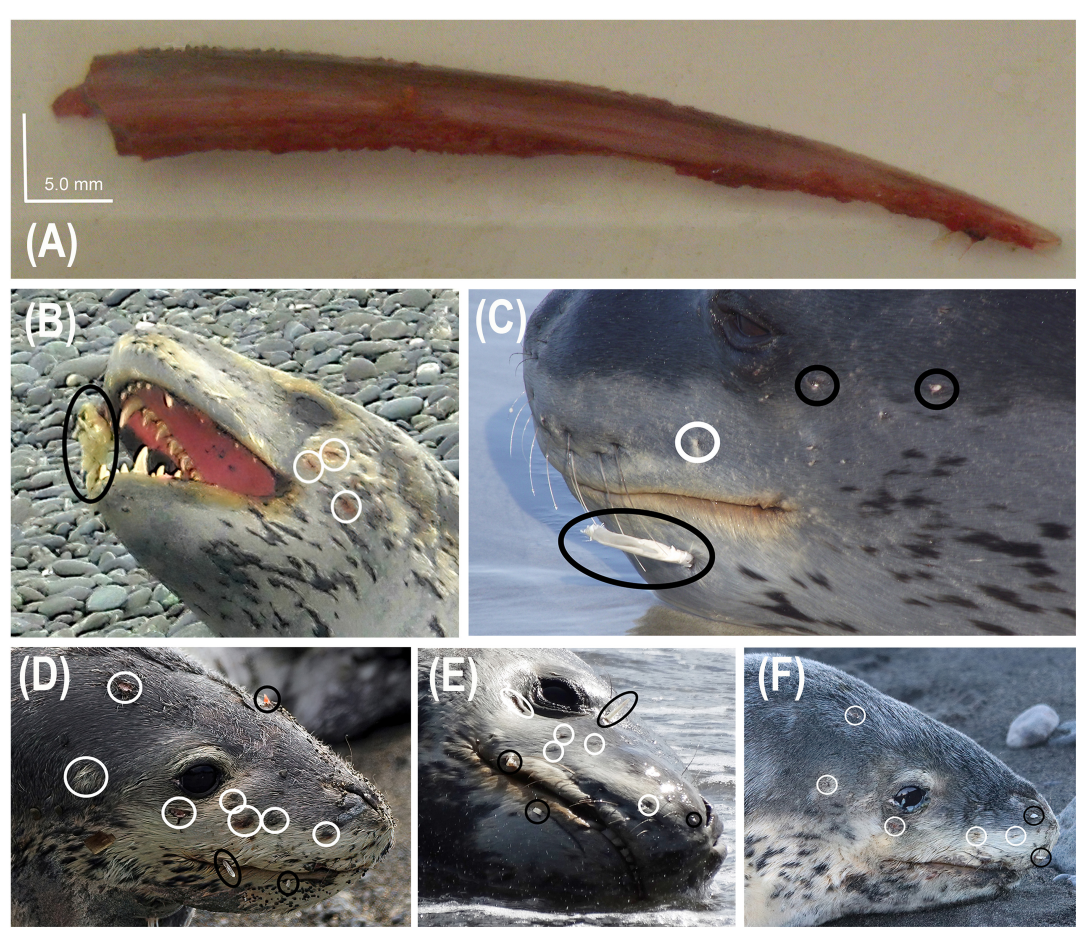

FIGURE 3 | Leopard seal (Hydrurga leptonyx) observations of predation in New Zealand, involving embedded dorsal fin spines from unidentified chimaeras (black circles) and puncture wounds (white circles) in the face from unidentified chimaeriforms: (A) dorsal fin spine recovered from deceased adult female HLNZ-P068, last sighted alive on 26 November 2009 at Waikouaiti Beach, Otago, photograph Otago Museum/Department of Conservation; (B) juvenile of unknown sex HLNZ-P043, sighted 15 October 2010, at Birdlings Flat, Canterbury, photograph Anita Spencer; (C) adult male HLNZ-030, sighted 20 September 2015, at Taieri Beach, Otago, photograph Kirsty Moffatt; (D) juvenile female HLNZ-P111, sighted 15 August 2018, at Pukeura Bay, Wellington, photograph Annabelle Tye; (E) HLNZ-P111 resighted on 18 August 2018, at Pukeura Bay, Wellington, photograph Kris Woods; (F) HLNZ-P111 resighted on 21 August 2018, at Ohawe Beach, Whanganui, photograph Karen Pratt.

\section{DISCUSSION}

\section{Detection of Leopard Seal Predation on Chondrichthyans}

Through a collaboration between researchers and citizen scientists, we collated 166 predation records for leopard seals in NZ. Of those, $10.8 \%$ provided, for the first time, evidence of predation on at least three chondrichthyan species; elephantfish, ghost shark and spiny dogfish, in all austral seasons and seven regions of NZ. There was a total of eighteen records from observations of chondrichthyan predation and scats (the latter confirmed via morphological and DNA sequencing assessments). As such the benefits of multifaceted methods are made clear and we strongly recommend that for all leopard seal diet studies in the future, non-fecal materials from scat undergo concurrent morphological examination and DNA sequencing. Reports of individual leopard seals favoring different types of prey (and different foraging techniques) have been recorded in the Antarctic (Krause et al., 2015). In NZ waters we identified three individuals each targeting chondrichthyans on multiple 
TABLE 6 | Scats collected which showed evidence of leopard seals (Hydrurga leptonyx) predating on chondrichthyans in New Zealand waters.

\begin{tabular}{|c|c|c|c|c|c|c|}
\hline $\begin{array}{l}\text { Date } \\
\text { (yyyymmdd) }\end{array}$ & Location & Age class, sex & NZLSC \# (Name) & Scat id. \# & Method for id. & $\begin{array}{l}\text { Chondrichthyan } \\
\text { species }\end{array}$ \\
\hline 20171009 & Nine Mile Beach, West Coast & Juvenile, Male & HLNZ-009 (Hatea) & HLs10 & Morph. and DNA & $\begin{array}{l}\text { Spiny dogfish } \\
\text { (Squalus acanthias) }\end{array}$ \\
\hline 20180108 & $\begin{array}{l}\text { Westhaven Marina, Waitemata } \\
\text { Harbour, Auckland }\end{array}$ & Adult, Female & $\begin{array}{l}\text { HLNZ-001 } \\
\text { (Owha) }\end{array}$ & HLs23 & Morph. & Spiny dogfish \\
\hline 20180307 & Long Beach, Purakaunui, Otago & $\mathrm{NK}^{1}$ & $\mathrm{NK}^{1}$ & HLs27 & Morph. & Spiny dogfish \\
\hline 20180907 & $\begin{array}{l}\text { Westhaven Marina, Waitemata } \\
\text { Harbour, Auckland }\end{array}$ & Adult, Female & $\begin{array}{l}\text { HLNZ-001 } \\
\text { (Owha) }\end{array}$ & HLs52 & Morph. and DNA & Spiny dogfish \\
\hline 20180914 & $\begin{array}{l}\text { Ocean View Beach, Ocean View, } \\
\text { Dunedin, Otago }\end{array}$ & Adult, Female & HLNZ-092 & HLs61 & Morph. & Spiny dogfish \\
\hline 20180925 & Aramoana Beach, Dunedin, Otago & Adult, Male & $\mathrm{NK}^{2}$ & HLs62 & Morph. and DNA & Spiny dogfish \\
\hline 20180929 & Oamaru Penguin Colony, Otago & Adult, Female & HLNZ-093 & HLs63 & Morph. and DNA & Spiny dogfish \\
\hline 20181022 & Waikouaiti Beach, Dunedin, Otago & Adult, Female & HLNZ-092 & HLs64 & Morph. and DNA & Spiny dogfish \\
\hline 20190830 & Spencerville Beach, Canterbury & Adult, $\mathrm{NK}^{3}$ & HLNZ-P099 & HLs84 & Morph. and DNA & Spiny dogfish \\
\hline
\end{tabular}

New Zealand Leopard Seal Catalogue (NZLSC) \# (Name) refers to the unique identifying number and 'nickname' assigned to leopard seals in the NZLSC (see methods for further details). Method for identification (id.) refers to either morphological examination (Morph.) and/or DNA sequencing (DNA) (see methods for further details). NK, not known.

${ }^{1}$ Photographs were not provided and therefore this seal could not be entered into or matched to the NZLSC, and its age class and sex could not be determined.

${ }^{2}$ Photographs provided were not sufficient for photo-identification and therefore this seal could not be entered into or matched to the NZLSC.

${ }^{3}$ Photographs provided were not sufficient for determining sex.

occasions and as such we expect that similar foraging preferences exist for a larger number of leopard seals in these waters.

\section{Importance of Citizen Science in Prey Data Collection}

The application of citizen science as an ecological research tool has increased in popularity in recent years, due to its ability to extend the spatial and temporal scope of analyses far beyond the limits of traditional field studies (Dickinson et al., 2010; Wilson et al., 2013; Earp and Liconti, 2020; Garcia-Cegarra et al., 2021). There are several benefits to using citizen scientists to collect data inter alia the ability to: (a) collect data in a comparatively inexpensive way (e.g., Evans and Hammond, 2004; Kiszka et al., 2007; Moura et al., 2012); (b) extensively cover regions where little information is known, on a regular basis (e.g., Visser, 2000; Evans and Hammond, 2004; Hupman et al., 2015) and (c) educate and engage members of the public about conservation (Earp and Liconti, 2020). NZ has a long history of successfully working with citizen scientists to collect data on marine mammals (e.g., Visser, 2000); however, the use of such data for pinniped studies is limited and more recent (e.g., Boren et al., 2008; Chilvers and Dobbins, 2021). In an effort to increase leopard seal data collection in NZ, LeopardSeals.org (since its foundation in 2016) has encouraged citizen scientists to submit leopard seal sightings data through a number of channels. The results herein, where $48.8 \%$ of the data was sourced from citizen scientists, highlights the importance of working with citizen scientists and the value that such a collaboration can contribute toward better understanding leopard seal predation. As such, the merit of citizen science is once again reaffirmed and we encourage more of this type of collaboration to be implemented around the country for a wider range of species.

\section{Distributions of the Chondrichthyan Prey}

The NZ spatial distributions of elephantfish (Francis, 1997; Roberts et al., 2015; MacGibbon et al., 2019), ghost sharks
(Roberts et al., 2015; MacGibbon et al., 2019; Finucci et al., 2020) and spiny dogfish (Manning et al., 2004; Dunn et al., 2009; Roberts et al., 2015; MacGibbon et al., 2019) overlap with the NZ spatial distribution of leopard seals (Hupman et al., 2020), as well as overlap with the leopard seal predation locations described herein.

However, elephantfish, ghost sharks and spiny dogfish are all known to be more abundant off the South Island (Roberts et al., 2015) as these species prefer colder waters (Dunn et al., 2009; Roberts et al., 2015). Dunn et al. (2009) also lists chimeras (ghost sharks) and spiny dogfish as species which are 'southern' or have the center of their NZ biomass in southern waters. Concurrently, chondrichthyans are reported less around the North Island, although that may be partly because there is limited surveying/deep-water fishing. Therefore, it is not surprising to find that only $4.4 \%$ of our North Island records included chondrichthyans, compared to $42.9 \%$ of our South Island records.

Furthermore, the depth distribution of elephantfish, ghost sharks and spiny dogfish overlaps with the known diving range for leopard seals; elephantfish are most abundant at depths of approximately $200 \mathrm{~m}$ (Roberts et al., 2015) and ghost sharks are widely distributed along the continental shelf and slope to depths of over $1500 \mathrm{~m}$ (Roberts et al., 2015). Two endemic species, the dark ghostshark and the pale ghostshark (Hydrolagus bemisi), are frequently captured in commercial fisheries and research surveys, generally at depths of 100-600 m and 400-1100 m respectively (McMillan et al., 2019); however, the dark ghost shark has been reported as shallow as $32 \mathrm{~m}$ (Roberts et al., 2015). Spiny dogfish are found on the continental shelf and upper slope down to depths of at least $500 \mathrm{~m}$ but are most common at depths of 50-150 m (Manning et al., 2004). Their depth distributions are dependent on their reproductive activity with their preferred depth changing with raising embryos (100 m or less), birthing (200-300 m) and mating (deeper waters) (Fisheries New Zealand, 2020). In comparison, leopard seals are relatively shallow divers, with their mean foraging dive depth being $15 \mathrm{~m}$ (at Livingston 
Island, Antarctic Peninsula; Krause et al., 2016), with, their known diving range extending down to $400 \mathrm{~m}$ (at Queen Maud Land, Antarctica; Nordøy and Blix, 2009). However, considering that ghost sharks are typically a deep diving species, the records of predation may indicate that leopard seals are diving to deeper depths in NZ waters or that they are targeting these fish when they are in the shallow sectors of their distribution. Likewise, it cannot be excluded that leopard seals may conduct kleptoparasitism in order to obtain ghost sharks [as has been documented by leopard seals taking Antarctic fur seal (Arctocephalus gazella) prey from conspecifics (Krause et al., 2015)]. Nor can it be excluded that the leopard seals may have scavenged the ghost sharks from commercial fisheries discards ${ }^{6}$.

\section{Importance of Chondrichthyans in Pinniped Diets}

Chondrichthyans have been recorded as prey for several other pinnipeds, e.g., Australian fur seals (Arctocephalus pusillus doriferus) feeding on elephantfish (Hocking et al., 2016), angel sharks (family Squatinidae) (Hocking et al., 2016) and wobbegong sharks (Orectolobus ornatus) (Allen and Huveneers, 2005); Cape fur seals (Arctocephalus pusillus pusillus) predating on blue sharks (Prionace glauca; Fallows et al., 2015) and puffadder shysharks (Haploblepharus edwardsii; Martin, 2004); NZ fur seals feeding on elephantfish (Emami-Khoyi et al., 2016; Hocking et al., 2020) and NZ sea lions, feeding on rough skates (Lalas, 1997; Lalas et al., 2007; Lalas and Webster, 2014; Roberts and Lalas, 2015).

While, chondrichthyans, collectively, appear to be a commonly targeted prey type for pinnipeds worldwide, within this Class of fishes, data suggests there are varying degrees's of importance for each Family and each pinniped species. For example, to the best of our knowledge, only three publications to date describe elephantfish as prey items for pinnipeds (Australian and NZ fur seals, Hocking et al., 2016, 2020; NZ fur seal, Emami-Khoyi et al., 2016). Emami-Khoyi et al. (2016) describes elephantfish as being "common" in NZ waters and that cartilaginous species (which include elephantfish) "constitute an important part of the NZ fur seal diet." Additionally, anecdotal reports of Cape fur seals with Cape elephantfish (Callorhinchus capensis) spines (Naude Dreyer pers. comm. ${ }^{7}$ ) embedded in their flesh have been observed.

Spiny dogfish have been well described in the published literature as a prey item for many pinnipeds including the Australian fur (e.g., Gales and Pemberton, 1994), gray (Halichoerus grypus; e.g., Byron and Morgan, 2016; Ono et al., 2019), harbor (e.g., Lance and Jeffries, 2007; Askin et al., 2012; Bromaghin et al., 2013; Byron and Morgan, 2016), Northern elephant (e.g., Huey, 1930; Antonelis et al., 1994; Sinclair, 1994)

\footnotetext{
${ }^{6}$ Although we note that it is generally illegal to discard ghost sharks in NZ waters (under Schedule 6 of the Fisheries Act 1996 - https://www.legislation. govt.nz/act/public/1996/0088/latest/DLM401761.html), given that leopard seals have been caught in NZ (Rowe, 2009; Abraham and Thompson, 2011; Berkenbusch et al., 2013; Abraham et al., 2017) and Australian (Shaughnessy et al., 2003) commercial fishing gear, such behavior from the leopard seals cannot be discounted.

${ }^{7}$ Information provided by Naude Dreyer from Ocean Conservation Namibia.
}

and NZ fur (e.g., Fea et al., 1999; Holborow, 1999; Harcourt et al., 2002; Boren, 2010) seals. Generally, however, they do not appear to constitute an important part of the overall diet; for example, Gales and Pemberton (1994) examined 317 scats and 40 regurgitates from Australian fur seals and found only $0.6 \%$ $(n=2)$ of records contained spiny dogfish. Likewise, Fea et al. (1999) examined 500 scats and 84 regurgitates from NZ fur seals and found only $0.2 \%(n=1)$ of records containing spiny dogfish. Comparatively, we found $6 \%(n=10)$ of records from NZ leopard seals contained spiny dogfish.

\section{Intraguild and Predator/Prey Relationships}

Intraguild predation (IGP) is the killing or consuming of species that are also predators (Polis et al., 1989). Some examples of IGP in pinnipeds include Cape fur seals feeding on blue sharks (Fallows et al., 2015) and Australian fur seals feeding on wobbegong sharks (Allen and Huveneers, 2005). Extensive evidence exists for leopard seals conducting IGP, through predation on other pinnipeds including; Antarctic (Hiruki et al., 1999; McKinlay et al., 2014), Sub-Antarctic (Arctocephalus tropicalis; Rogers, 2009) and Juan Fernández fur seals (Arctocephalus philippii; Croxall and Gentry, 1987), crabeater (Bengtson et al., 2011), Ross (Ommatophoca rossii; Hall-Aspland and Rogers, 2007), Weddell (Hall-Aspland and Rogers, 2007) and Southern elephant (Mirounga leonine; Forcada et al., 2009) seals, and Australian (Neophoca cinereal; Rogers, 2009), NZ (Harcourt, 2001) and South American (Otaria byronia; Dawson, 1974) sea lions. In this paper, we presented the first evidence of IGP involving leopard seals feeding on sharks (i.e., predation on spiny dogfish). Such predation may also represent competition with the NZ Coastal orca who are known to feed extensively on elasmobranchs (Visser, 1999, 2005; Visser et al., 2000) including on spiny dogfish (Visser, unpublished data).

\section{Comparison Between Morphological Examination and DNA Sequencing}

The chondrichthyans preyed upon by NZ leopard seals are amongst the most commonly observed cartilaginous fishes in NZ waters, particularly in inshore marine environments (McMillan et al., 2019). When consumed by Australian fur seals, the cartilaginous skeletons of chondrichthyans do not always survive digestion (Deagle et al., 2009). Conversely, we found that spiny dogfish vertebra were the most numerous prey remains discovered in the NZ leopard seal scats. Cartilaginous skeletons may have been able to survive digestion in our study due to leopard seals consuming chondrichthyans relatively close to shore and they are consequently passed in feces on land. Alternatively, leopard seals may have consumed a larger proportion of their prey (compared to smaller pinnipeds like NZ fur seals which may only eat part of the prey) and thereby they may ingest more of the cartilaginous skeleton, increasing the probability that vertebrae are deposited in scats. Logically, these two scenarios are not mutually exclusive. We must however note, that chondrichthyan consumption may also still occur offshore, and feces may then consequently be passed offshore, 
which thereby reduces the likelihood of detection in subsequent scats which may be deposited on land (Fallows et al., 2015). Therefore, the percentage of scats which contain chondrichthyan remains may not be a true reflection of overall consumption and chondrichthyans may make up a larger proportion of the diet of leopard seals in NZ waters than the current samples indicate.

The relatively new development of cost-effective DNA sequencing has shed light on some pinniped diets (e.g., Deagle et al., 2009; Peters et al., 2015; Emami-Khoyi et al., 2016; Goldsworthy et al., 2019) and has shown itself to be an alternative (and very sensitive) method for detecting and identifying rarer prey items (Purcell et al., 2004; Deagle et al., 2005, 2009). For example, Deagle et al. (2009) examined 490 scats from Australian fur seals using morphological analysis and identified 39 distinct fish groups ( $8 \%$ detection rate), whereas upon examining 90 scats using DNA sequencing, they identified 35 distinct fish groups (38.9\% detection rate).

In our study, only one species of chondrichthyan (spiny dogfish) was found in leopard seal scats. It was detected via both morphological examination and DNA sequencing, but we found that morphological analysis was more accurate than DNA sequencing. To illustrate, in six scats chondrichthyans were detected via morphological analysis and DNA sequencing. However, chondrichthyans were detected in three additional scats via morphological examination, yet these were not detected via DNA sequencing due to the samples being too degraded to detect DNA.

\section{Cause/Origin of Intact Prey Items}

We recorded three instances where leopard seals were hauled out and prey was either partially ingested (a ghost shark, Figure 2A), or laying alongside (an elephantfish, Figure 2B and a spiny dogfish, Figure 2C). We hypothesize that the reason the prey was intact could have been due to the leopard seals: (a) capturing the prey and bringing it ashore; (b) capturing the prey, ingesting it in water and regurgitating it ashore; (c) coming ashore where the fishes were already (and ignoring them); (d) scavenging the prey ashore or (e) undergoing human interference, where the prey was placed next to the seal (and it may or may not have been ingested).

The only published account of leopard seal predation on land, that we could locate, was described at Macquarie Island where a young animal in poor condition was seen to catch and kill two Gentoo penguins. However, the author Erb (1993) described the account as "irrational and untypical behavior" for leopard seals. Evidence of leopard seals caching prey, has however been repeatedly documented ( $n=11$ observations) (Krause et al., 2015; Krause and Rogers, 2019). One of these observations, on Bird Island, South Georgia, involved a leopard seal carrying a dead Gentoo Penguin (Pygoscelis papua) in its mouth as it hauled onto a rocky beach (Krause and Rogers, 2019). Such prey caching behavior makes it plausible that the leopard seals observed in this study may have captured their prey at sea and then brought it onshore. This is further supported by the apparent puncture marks in the spiny dogfish (not shown herein, but which were similar in spacing to that of a leopard seal's canines, i.e., $7 \mathrm{~cm}$, see Marlow, 1967).
An alternative hypothesis that the prey laying alongside the leopard seals had been regurgitated seems unlikely considering none of the prey showed any signs of digestive erosion of the skin. It also seems highly coincidental, and therefore also unlikely, that these leopard seals would come ashore specifically where prey would be laying. Additionally, although leopard seals have been previously observed scavenging discarded carcasses (penguin and fur seal pups; Krause et al., 2015), these were in the water. Lastly, while human interference cannot be ruled out (i.e., by positioning these prey items alongside the leopard seals), it doesn't seem the most plausible explanation for the intact prey, as compared to the leopard seals capturing the prey and bringing it ashore.

Our record of a ghost shark in the leopard seals mouth could also be an attempt to swallow it whole (rather than biting), albeit that it was not able to do so. The shark, estimated to be at least $40 \mathrm{~cm}$ long, appeared to be in one piece (at least from the pectoral fins to the tail, i.e., the section that was protruding from the seal's mouth) and it may have been too large to be swallowed. Leopard seals have been documented feeding with a conspecific to tear penguins apart (Robbins et al., 2019) and in this instance the leopard seal could have benefited from such corporation, however no other leopard seals were present.

\section{Prey-Induced Injuries}

We reported six cases involving 12 dorsal fin spines of chimaeroids which were embedded in the face of leopard seals, and a further 11 puncture wounds causing injuries (Table 5 and Figure 3). Chimaeroids have one or more long, mildly poisonous spine(s) anterior to the dorsal fin(s), presumed to be for defensive purposes (Didier, 1995) and it is these spines which become embedded in the leopard seal's faces. Similar injuries have been reported for leopard seals in Australia, where spines of stingrays were found embedded in their flesh (Elliot, 1982; King, 1983; Rounsevell and Pemberton, 1994; Warneke, 1995). These injuries often cause wounds and abscesses, and while surface wounds will heal, deeper penetration may cause lethal infections (King, 1983).

While, to our knowledge, a leopard seal has never been reported to have died from such an embedment, it could be possible, considering the published accounts of other pinniped mortality caused by spines perforating the esophagus or stomach of the pinnipeds and then migrating into vital tissues (e.g., Akmajian et al., 2012). However, for one deceased animal (NZLSC number HLNZ-P068; Table 5) a necropsy ${ }^{8}$ was conducted which documented a spine embedment in the face which may have contributed to the death, but the evidence was only speculative; "I am suspicious that she may have died from pneumonia (possibly bacterial), this may have been aggravated by difficulty eating due to the stingray sting [sic] ${ }^{9}$."

We hypothesize that wounds such as those illustrated herein likely occur when leopard seals thrash their prey at the waters surface, accidentally inflicting themselves with the dorsal fin spine(s). This is the same process as described in Hocking et al.

\footnotetext{
${ }^{8}$ The necropsy was conducted on $02 / 02 / 2010$ by Dr. Pauline Howard (DVM) in Christchurch, NZ.

${ }^{9}$ Quote from Dr. Pauline Howard (DMV) necropsy report (2010). The
} chondrichthyan spine was originally (erroneously) identified as a 'stingray sting.' 
(2020), where NZ fur seals were described to strongly shake their prey to process it, subsequently injuring themselves with the dorsal fin spines. An alternative, non-competing hypothesis is that the prey thrashes their bodies around after they are caught in the leopard seals jaw, such that they arch their body enough to force their dorsal fin spine into the leopard seals face. Of course, it cannot be ruled out that the actions by both the predator and prey, occur concurrently or sequentially to create these wounds. The other main type of injury is where the dorsal fin spines pierce around the lips and mouth of the seal, which potentially occurs when the seal bites down on the prey (e.g., Figure 3B). Some chimaeroids are likely too large to swallow whole (e.g., Figure 2A) and yet the act of processing (i.e., strongly shaking) this type of prey carries the risk of injury. While the risk of injury (or café syndrome, which arises from preyrelated asphyxiation, e.g., see Stroud, 1979) does not appear to deter leopard seals from predating on chimaeroids, one would suspect it would discourage them from targeting this type of prey. However, some may master avoiding the dorsal fin spines. Examples of dorsal fin spine avoidance has been documented in studies of Australian fur seals predating on elephantfish, where they process the prey from the ventral side, thus avoiding injury from the dorsal fin spine (see Hocking et al., 2016, figure 4e; Hocking et al., 2020, Supplementary Figure 1I). Considering spine avoidance is possible, it is plausible that such injuries may reflect inexperienced prey catching behavior (Rounsevell and Pemberton, 1994) which one would expect from juveniles, yet there were significantly less juveniles in our study, than adults. However, the animal with the most records of chondrichthyan predation $(n=4)$ was a juvenile, suggesting that such a learning process may have been ongoing.

The tooth wear and fair body condition of HLNZ-P068, indicates that this animal was not in good health. All the remaining leopard seals reported herein, that could be assessed for tooth wear and body condition showed no tooth wear and good or excellent body condition, which supports the theory that consumption of chimeras was not due to limited prey availability or driven by desperation feeding. Instead, we hypothesize that leopard seals are consuming chimeras (a) purposely, despite the injury risk it poses or (b) naively, during opportunistic prey capture, not knowing the risks it poses. A similar hypothesis was proposed for harbor seals in good condition, which exhibited embedded spines from predation on spotted ratfish and similarly, their choice of prey was not considered 'desperation feeding' (Akmajian et al., 2012).

Purposeful selection of chimaeroids as prey is further supported in this study specifically through one individual's diet preferences; HLNZ-P111 was found with a spiny dogfish adjacent to it (Table 4 and Figure 2C) and unidentified chimaeriform dorsal fin spines embedded in its face on multiple occasions (Table 5 and Figure 3). These observations occurred over a seven-day period and in two different regions (Tables 4, 5). Spiny dogfish have two dorsal fins and two spines. Considering that this leopard seal showed an accumulated seven dorsal fin spines embedded in its face over a 7-day period, one could speculate that at the very least four predation events occurred during this period, although seven may also have occurred (spiny dogfish have two dorsal fins and two spines, whilst other chimaeroids typically have one long spine anterior to the dorsal fin). Given the spine embedment's near the sensory organs (eyes, nostrils and whiskers) of the leopard seals documented herein, chimeroids are clearly high-risk prey for leopard seals. Although the seals may employ distinct hunting tactics to mitigate such risks, other than the potential learning curve mentioned herein, these have yet to be documented.

\section{Further Research}

Unlike other areas of the leopard seal's core range (i.e., Antarctic waters), which are usually difficult to access and prohibit yearround systematic observations of predation and/or collection of scats (Casaux et al., 2009), NZ's coastal environment is relatively accessible year-round. With leopard seals being a 'Resident' species in NZ waters, and with some individuals occupying areas near highly urbanized regions, and over extended periods of time, we have had the opportunity to conduct focused monitoring of individuals (Hupman et al., 2020). Such access is particularly relevant with respect to the increasing interest by citizen scientists (Hupman et al., 2020), as it improves opportunities for them to contribute to leopard seal conservation in NZ. As environmental conditions continue to change (e.g., Evans and Waggitt, 2020) and anthropogenic stressors continue to rise, collecting leopard seal prey data is crucial to further our understanding of the complex predator/prey relationships in existence including the drivers behind NZ leopard seals feeding on chondrichthyans. To facilitate better management/protection of this species in NZ, we therefore recommend that additional necropsies, observations of predation and collection of scats are undertaken with priority.

\section{DATA AVAILABILITY STATEMENT}

The datasets presented in this study can be found in online repositories. The names of the repository/repositories and accession number(s) can be found below: NCBI (accession: OK632081-OK632086).

\section{AUTHOR CONTRIBUTIONS}

$\mathrm{KL}, \mathrm{IV}, \mathrm{RB}$, and JF collected the field data. KL generated the databases with assistance from IV, RB, CL, and LS. KL and IV contributed to the conception and design of the study. KL wrote the first draft of the manuscript and performed the data analysis. IV wrote sections of the manuscript and prepared the figures. CL and LS completed prey species analysis. All authors contributed to manuscript editing and approved the submitted version.

\section{FUNDING}

This work was conducted under permit numbers 63499-MAR (KL) and 63877-MAR (IV) issued by the Department of Conservation. Funding was provided by NIWA Coasts \& Oceans SSIF, Programme 4 'Marine ecosystem dynamics'. We thank 
Dodoland and Dolphin Encounter for their financial support of LeopardSeals.org.

\section{ACKNOWLEDGMENTS}

We thank the Department of Conservation for providing details of sightings from the marine mammal sightings database. We are also indebted to everyone who reported sightings and photographs to LeopardSeals.org including many DOC staff, marine researchers, NIWA staff, marinas, boating clubs, and citizen scientists. We thank the multiple volunteers of LeopardSeals.org who have monitored leopard seals around $\mathrm{NZ}$ and who have assisted in data collation. We specifically thank those individuals and citizen scientists who attended and reported observations of predation (Robin Ashton, Siobahan Ashworth, Kirsty Moffatt, Stuart Moffatt, Sue Parsons, Karen Pratt, Tony Quale, Anita Spencer, Kris Woods, and Annabelle Tye) or collected scats (Giverny Forbes, Warren Hunt, Rosemary Jackson-Hunter, Julie Leighton, Brittany Mathias, and Lynda

\section{REFERENCES}

Abraham, E. R., and Thompson, F. N. (2011). Summary of the Capture of Seabirds, Marine Mammals, and Turtles in New Zealand Commercial Fisheries, 1998-99 to 2008-09. New Zealand Aquatic Environment and Biodiversity Report 80 . Wellington: Ministry of Fisheries.

Abraham, E. R., Neubauer, P., Berkenbusch, K., and Richard, Y. (2017). Assessment of the Risk to New Zealand Marine Mammals from Commercial Fisheries. New Zealand Aquatic Environment and Biodiversity Report 189. Wellington: Ministry of Primary Industries.

Akmajian, A. M., Lambourn, D. M., Lance, M. M., Raverty, S., and Gaydos, J. K. (2012). Mortality related to spotted ratfish (Hydrolagus colliei) in Pacific harbor seals (Phoca vitulina) in Washington State. J. Wildl. Dis. 48, 1057-1062. doi: 10.7589/2011-12-348

Allen, S., and Huveneers, C. (2005). First record of an Australian fur seal (Arctocephalus pusillus doriferus) feeding on a wobbegong shark (Orectolobus ornatus). Proc. Linn. Soc. N. S. W. 126, 95-97.

Antonelis, G. A., Lowry, M. S., Fiscus, C. H., Stewart, B. S., and DeLong, R. L. (1994). "Diet of the northern elephant seal," in Elephant Seals: Population Ecology, Behavior, and Physiology, eds B. J. Le Boeuf and R. M. Laws (Los Angeles, CA: University of California Press), 211-213. doi: 10.1525/ 9780520328150-013

Askin, N., Belanger, M., and Wittnich, C. (2012). Competitive feeding behavior interaction between a dogfish shark (Squalus acanthias) and a pinniped (Phoca vitulina). J. Anim. Ecol. 5, 6-8.

Bailey, A. M., and Sorensen, J. H. (1962). Subantarctic Campbell Island: Proceedings Number 10. Denver, CO: Denver Museum of Nature and Science Press.

Bengtson, J. L., Laake, J. L., Boveng, P. L., Cameron, M. F., Hanson, M. B., and Stewart, B. S. (2011). Distribution, density, and abundance of pack-ice seals in the Amundsen and Ross Seas, Antarctica. Deep Sea Res. Part II Top. 58, 1261-1276. doi: 10.1016/j.dsr2.2010.10.037

Berkenbusch, K., Abraham, E. R., and Torres, L. G. (2013). New Zealand Marine Mammals and Commercial Fisheries. New Zealand Aquatic Environment and Biodiversity Report 119. Wellington: Ministry for Primary Industries.

Boren, L. J. (2010). Diet of New Zealand fur Seals (Arctocephalus forsteri): A Summary. Wellington: New Zealand Department of Conservation.

Boren, L. J., Gemmell, N., and Barton, K. (2008). The role and presence of a guide: preliminary findings from swim with seal programs and land-based seal viewing in New Zealand. Tour. Mar. Environ. 5, 187-199. doi: 10.3727/ 154427308787716776

Bromaghin, J. F., Lance, M. M., Elliott, E. W., Jeffries, S. J., Acevedo-Gutiérrez, A., and Kennish, J. M. (2013). New insights into the diets of harbor seals (Phoca
Morrison). We thank Ella Benninghaus, Evelyn Hollaus, Samuel Langlois Lopez, Charlotte Patterson, Erin Vince, and Jodie Warren for their assistance processing scats. Special thanks to Dr. Pauline Howard and Otago Museum (specifically Emma Burns) for supplying information on the leopard seal known as Autahi and to Andrew Stewart (Otago Museum) for identifying the dorsal fin spine which was embedded in this animal. We thank Nicola Roos for her work examining our photo library for observations of predation. We are grateful to Alex Grabham for his work matching the individual leopard seals to the NZLSC. In addition, we thank Tracy Cooper, Anna Demchy and Shona Mackay for their assistance in sourcing references.

\section{SUPPLEMENTARY MATERIAL}

The Supplementary Material for this article can be found online at: https://www.frontiersin.org/articles/10.3389/fmars. 2021.795358/full\#supplementary-material

vitulina) in the Salish Sea revealed by analysis of fatty acid signatures. Fish. Bull. 111:13.

Byron, C., and Morgan, A. (2016). Potential role of spiny dogfish in gray and harbor seal diets in the Gulf of Maine. Mar. Ecol. Prog. Ser. 550, 249-270. doi: 10.3354/meps11718

Casaux, R., Baroni, A., Ramón, A., Carlini, A., Bertolin, M., and DiPrinzio, C. Y. (2009). Diet of the leopard seal Hydrurga leptonyx at the Danco Coast, Antarctic Peninsula. Polar Biol. 32, 307-310. doi: 10.1007/s00300-0080567-0

Chilvers, B. L., and Dobbins, M. L. (2021). Behavioural plasticity and population connectivity: contributors to the establishment of new pinniped breeding colonies. Aquat. Conserv. 31, 2217-2228.

Compagno, L. J. V. (1988). Sharks of the Order Carcharhiniformes. Princeton, NJ: Princeton University Press.

Croxall, J. P., and Gentry, R. L. (1987). “Status, biology, and ecology of fur seals," in Proceedings of an International Symposium and Workshop, Cambridge, England, 23-27 April 1984. NOAA Technical Report NMFS 51, Vol. 51, (Silver Spring, MD: United States Department of Commerce, National Marine Fisheries Service).

Cupples, J. B., Crowther, M. S., Story, G., and Letnic, M. (2011). Dietary overlap and prey selectivity among sympatric carnivores: could dingoes suppress foxes through competition for prey? J. Mammal. 92, 590-600. doi: 10.1644/10mamm-a-164.1

Dawson, E. W. (1974). Adelie penguins and leopard seals: illustrations of predation - history, legend and fact. Notornis 21, 36-69.

Deagle, B. E., Kirkwood, R., and Jarman, S. N. (2009). Analysis of Australian fur seal diet by pyrosequencing prey DNA in faeces. Mol. Ecol. 18, 2022-2038. doi: 10.1111/j.1365-294X.2009.04158.x

Deagle, B. E., Tollit, D. J., Jarman, S. N., Hindell, M. A., Trites, A. W., and Gales, N. J. (2005). Molecular scatology as a tool to study diet: analysis of prey DNA in scats from captive Steller sea lions. Mol. Ecol. 14, 1831-1842. doi: 10.1111/j.1365-294X.2005.02531.x

Department of Conservation (1990). Administrative Boundaries (C.1990). Wellington: New Zealand Department of Conservation.

Dickinson, J. L., Zuckerberg, B., and Bonter, D. N. (2010). Citizen science as an ecological research tool: challenges and benefits. Annu. Rev. Ecol. Evol. Syst. 41, 149-172.

Didier, D. A. (1995). Phylogenetic systematics of extant chimaeroid fishes (Holocephali, Chimaeroidei). Am. Mus. Novit. 3119, 1-86. doi: 10.1016/j. cretres.2013.09.011

Duffy, C. A. J., and Brown, D. A. (1994). Recent Observations of Marine Mammals and A Leatherback Turtle (Demwchelys coriacea) in the Marlborough Sounds, 
New Zealand, 1981-1990. Occasional Publication No.9. Nelson: Department of Conservation.

Dunn, M. R., Hurst, R. J., Renwick, J., Francis, R. I. C. C., Devine, J., and McKenzie, A. (2009). Fish Abundance and Climate Trends in New Zealand. New Zealand Aquatic Environment and Biodiversity Report 31:75. Wellington: National Institute of Water and Atmospheric Research.

Earp, H. S., and Liconti, A. (2020). "Science for the future: the use of citizen science in marine research and conservation," in YOUMARES 9-The Oceans: Our Research, Our Future: Proceedings of the 2018 Conference for Young Marine Researcher in Oldenburg, Germany, eds S. Jungblut, V. Liebich, and M. BodeDalby (Basingstoke: Springer Nature), 1-18. doi: 10.1007/978-3-030-20389-4_1

Elliot, M. (1982). Comparison of Macquarie Island and NSW leopard seal records with notes on their diet. Thylacinus 7, 10-15.

Emami-Khoyi, A., Hartley, D. A., Paterson, A. M., Boren, L. J., Cruickshank, R. H., Ross, J. G., et al. (2016). Identifying prey items from New Zealand fur seal (Arctocephalus forsteri) faeces using massive parallel sequencing. Conserv. Genet. Resour. 8, 343-352. doi: 10.1007/s12686-016-0560-9

Erb, E. (1993). "Some field observations on leopard seals (Hydrurga leptonyx) at Heard Island 1992/93," in Heard Island 1992 ANARE Report, ed. K. Green (Kingston, TAS: Australian Antarctic Division), 48-66.

Evans, P. G. H., and Hammond, P. S. (2004). Monitoring cetaceans in European waters. Mammal Rev. 34, 131-156. doi: 10.1046/j.0305-1838.2003.00027.x

Evans, P. G. H., and Waggitt, J. J. (2020). Impacts of climate change on marine mammals, relevant to the coastal and marine environment around the UK. MCCIP Sci. Rev. 2020, 420-454. doi: 10.1007/s00248-013-0204-5

Fallows, C., Benoit, H. P., and Hammerschlag, N. (2015). Intraguild predation and partial consumption of blue sharks Prionace glauca by Cape fur seals Arctocephalus pusillus pusillus. Afr. J. Mar. Sci. 31, 125-128. doi: 10.2989/ 1814232X.2015.1013058

Fea, N. I., Harcourt, R., and Lalas, C. (1999). Seasonal variation in the diet of New Zealand fur seals (Arctocephalus forsteri) at Otago Peninsula, New Zealand. Wildl. Res. 26, 147-160.

Finucci, B., Cheok, J., Ebert, D. A., Herman, K., Kyne, P. M., and Dulvy, N. K. (2020). Ghosts of the deep - biodiversity, fisheries, and extinction risk of ghost sharks. Fish Fish. 22, 391-412. doi: 10.1111/faf.12526

Fisheries New Zealand (2020). Fisheries Assessment Plenary, May 2020: Stock Assessments and Stock Status. Wellington: Fisheries Science and Information Group, Fisheries New Zealand New Zealand.

Forcada, J., Malone, D., Royle, J. A., and Staniland, I. J. (2009). Modelling predation by transient leopard seals for an ecosystem-based management of Southern Ocean fisheries. Ecol. Modell. 220, 1513-1521. doi: 10.1016/j.ecolmodel.2009. 03.020

Francis, M. P. (1997). Spatial and temporal variation in the growth rate of elephantfish (Callorhinchus milii). N. Z. J. Mar. 31, 9-23.

Gales, R., and Pemberton, D. (1994). Diet of the Australian fur seal in Tasmania. Aust. J. Mar. Freshw. Res. 45, 653-654. doi: 10.1071/mf9940653

Garcia-Cegarra, A. M., Toro, F., and Gonzalez-Borasca, V. (2021). Citizen science as a tool to assess cetacean diversity in the Atacama Desert coast. Ocean Coast. Manag. 213:105858.

Gigliotti, L. C., Slotow, R., Hunter, L. T., Fattebert, J., Sholto-Douglas, C., and Jachowski, D. S. (2020). Habitat complexity and lifetime predation risk influence mesopredator survival in a multi-predator system. Sci. Rep. 10:17841. doi: 10.1038/s41598-020-73318-3

Goldsworthy, S. D., Bailleul, F., Nursey-Bray, M., Mackay, A., Oxley, A., Reinhold, S.-L., et al. (2019). Assessment of the Impacts of Seal Populations on the Seafood Industry in South Australia. FRDC Project Number 2013/011. Urrbrae, SA: South Australian Research and Development Institute.

Gravendeel, R., Van Neer, W., and Brinkhuizen, D. (2002). An identification key for dermal denticles of Rajidae from the North Sea. Int. J. Osteoarchaeol. 12, 420-441. doi: 10.1002/oa.645

Guy, G. (1947). Food of sea leopard. Notornis 2:133.

Hall-Aspland, S. A., and Rogers, T. L. (2004). Summer diet of leopard seals (Hydrurga leptonyx) in Prydz Bay, Eastern Antarctica. Polar Biol. 27, 729-734. doi: 10.1007/s00300-004-0662-9

Hall-Aspland, S., and Rogers, T. (2007). Identification of hairs found in leopard seal (Hydrurga leptonyx) scats. Polar Biol. 30, 581-585.

Hamilton, J. L. (1939). The leopard seal, Hydrurga leptonyx (de Blainville). Discov. Rep. 18, 239-264.
Harcourt, R. G. (2001). Advances in New Zealand mammalogy 1990-2000: pinnipeds. J. R. Soc. N. Z. 31, 135-160.

Harcourt, R. G., Bradshaw, C. J., Dickson, K., and Davis, L. S. (2002). Foraging ecology of a generalist predator, the female New Zealand fur seal. Mar. Ecol. Prog. Ser. 227, 11-24. doi: 10.3354/meps227011

Hiruki, L. M., Schwartz, M. K., and Boveng, P. (1999). Hunting and social behaviour of leopard seals (Hydrurga leptonyx) at Seal Island, South Shetland Islands, Antarctica. J. Zool. Soc. London 249, 97-109. doi: 10.1111/j.1469-7998. 1999.tb01063.x

Hocking, D. P., Evans, A. R., and Fitzgerald, E. M. G. (2013). Leopard seals (Hydrurga leptonyx) use suction and filter feeding when hunting small prey underwater. Polar Biol. 36, 211-222. doi: 10.1007/s00300-012-1253-9

Hocking, D. P., Fitzgerald, E. M. G., Salverson, M., and Evans, A. R. (2016). Prey capture and processing behaviours vary with prey size and shape in Australian and subantarctic fur seals. Mar. Mamm. Sci. 32, 568-587.

Hocking, D. P., Marx, F. G., Parker, W. M. G., Rule, J. P., Cleuren, S. G. C., Mitchell, A. D., et al. (2020). Inferring diet, feeding behaviour and causes of mortality from prey-induced injuries in a New Zealand fur seal. Dis. Aquat. Organ. 139, 81-86. doi: 10.3354/dao03473

Hocking, D. P., Marx, F., Wang, S., Burton, D., Thompson, M., Park, T., et al. (2021). Convergent evolution of forelimb-propelled swimming in seals. Curr. Biol. 31, 2404-2409.e2. doi: 10.1016/j.cub.2021.03.019

Holborow, J. (1999). The Diet of New Zealand fur Seals (Arctocephalus forsteri) in Southern New Zealand. [Master's thesis]. Otago: University of Otago.

Horning, D. S. Jr., and Fenwick, G. D. (1978). Leopard seals at the Snares islands, New Zealand. N. Z. J. Zool. 5, 171-172. doi: 10.1080/03014223.1978. 10423747

Huey, L. M. (1930). Past and present status of the northern elephant seal with a note on the Guadalupe fur seal. J. Mammal. 11, 188-194. doi: 10.2307/1374066

Hupman, K., Visser, I. N., Martinez, E., and Stockin, K. A. (2015). Using platforms of opportunity to determine the occurrence and group characteristics of orca (Orcinus orca) in the Hauraki Gulf, New Zealand. N. Z. J. Mar. Freshw. Res. 49, 132-149. doi: 10.1080/00288330.2014.980278

Hupman, K., Visser, I. N., Fyfe, J., Cawthorn, M., Forbes, G., Grabham, A. A., et al. (2020). From Vagrant to Resident: occurrence, residency and births of leopard seals (Hydrurga leptonyx) in New Zealand waters. N. Z. J. Mar. 54, 1-23.

Johnston, T. H., and Mawson, P. M. (1953). Parasitic nematodes and trematodes from Campbell and Auckland Islands (Cape Expedition). Rec. Dom. Mus. 2, 63-71.

King, J. E. (1983). Seals of the World. England: British Museum. (Natural History).

Kiszka, J. J., Heithaus, M. R., and Wirsing, A. J. (2015). Behavioural drivers of the ecological roles and importance of marine mammals. Mar. Ecol. Prog. Ser. 523, 267-281.

Kiszka, J., Macleod, K., Van Canneyt, O., Walker, D., and Ridoux, V. (2007). Distribution, encounter rates, and habitat characteristics of toothed cetaceans in the Bay of Biscay and adjacent waters from platform of opportunity data. ICES Mar. Sci. Symp. 64, 1033-1043.

Kooyman, G. L. (1981). "Leopard seal (Hydrurga leptonyx Blainville, 1820)," in Handbook of Marine Mammals, eds S. Ridgway and R. Harrison (London: Academic Press), 261-272.

Krause, D. J., and Rogers, T. L. (2019). Food caching by a marine apex predator, the leopard seal (Hydrurga leptonyx). Can. J. Zool. 97, 573-578.

Krause, D. J., Goebel, M. E., and Kurle, C. M. (2020). Leopard seal diets in a rapidly warming polar region vary by year, season, sex, and body size. BMC Ecol. 20:32. doi: 10.1186/s12898-020-00300-y

Krause, D. J., Goebel, M. E., Marshall, G. J., and Abernathy, K. (2015). Novel foraging strategies observed in a growing leopard seal (Hydrurga leptonyx) population at Livingston Island, Antarctic Peninsula. Anim. Biotelem. 3, 1-14. doi: 10.1186/s40317-015-0059-2

Krause, D. J., Goebel, M. E., Marshall, G. J., and Abernathy, K. (2016). Summer diving and haul-out behavior of leopard seals (Hydrurga leptonyx) near mesopredator breeding colonies at Livingston Island, Antarctic Peninsula. Mar. Mamm. Sci. 32, 839-867. doi: 10.1111/mms. 12309

Lalas, C. (1997). "Prey of Hooker's sea lions Phocarctos hookeri based at Otago Peninsula New Zealand," in Marine Mammal Research in the Southern 
Hemisphere, Volume 1: Status, Ecology And Medicine, eds M. Hindell and C. Kempker (Chipping Norton: Surrey Beatty and Sons), 130-136.

Lalas, C., and Webster, T. (2014). Contrast in the importance of arrow squid as prey of male New Zealand sea lions and New Zealand fur seals at The Snares, subantarctic New Zealand. Mar. Biol. 161, 631-643.

Lalas, C., Ratz, H., McEwan, K., and McConkey, S. D. (2007). Predation by New Zealand sea lions (Phocarctos hookeri) as a threat to the viability of yelloweyed penguins (Megadyptes antipodes) at Otago Peninsula, New Zealand. Biol. Conserv. 135, 235-246.

Lance, M. M., and Jeffries, S. J. (2007). Temporal and Spatial Variability of Harbor Seal Diet in the San Juan Island Archipelago. Contract Report to SeaDoc Society Research Agreement (K004431-25). Washington, DC: Washington Department of Fish and Wildlife Program.

Last, P. R., and Stevens, J. D. (2009). Sharks and Rays of Australia, 2nd Edn. Clayton, VIC: CSIRO Publishing.

Laws, R. M. (1984). Antarctic Ecology, Vol. 2. London: Academic Press.

Leach, F. (1997). A Guide to the Identification of Fish Remains from New Zealand Archaeological Sites. Wellington: New Zealand Journal of Archaeology.

MacGibbon, D. J., Beentjes, M. P., Lyon, W. L., and Ladroit, Y. (2019). Inshore Trawl Survey Of Canterbury Bight and Pegasus Bay, April-June 2018 (KAH1803). New Zealand Fisheries Assessment Report 2019/03. Wellington: Fisheries New Zealand.

Manning, M. J., Hanchet, S. M., and Stevenson, M. L. (2004). A Description and Analysis of New Zealands Spiny Dogfish (Squalus acanthias) fisheries and recommendations on appropriate methods to monitor the status of the stocks. Final research report for Ministry of Fisheries Research Project SPD2002-01, objective 1. Final Research Report. Wellington: National Institute of Water and Atmospheric Research.

Marlow, B. J. (1967). Mating behaviour in the leopard seal, Hydrurga leptonyx (Mammalia: Phocidae), in captivity. Aust. J. Zool. 15, 1-5. doi: 10.1071/ zo9670001

Martin, A. R. (2004). Natural mortality of the puffadder shyshark (Haploblepharus edwardsii) due to two species of marine tetrapod, the Cape fur seal (Arctocephalus pusillus pusillus) and black-backed kelp gull (Larus dominicanus vetula) at Seal Island, False Bay, South Africa. J. Fish Biol. 64, 711-716. doi: 10.1046/j.1095-8649.2003.00339.x

McEachran, J. D., and Konstantinou, H. (1996). Survey of the variation in alar and malar thorns in skates: phylogenetic implications (Chondrichthyes: Rajoidei). J. Morphol. 228, 165-178. doi: 10.1002/(SICI)1097-4687(199605)228:2\&lt;165:: AID-JMOR5\&gt;3.0.CO;2-4

McKinlay, B., Heseltine, S., and Loh, G. (2014). Seabird predation by vagrant leopard seals (Hydrurga leptonyx) at Otago, New Zealand. Notornis 61, 48-50.

McMillan, P. J., Francis, M. P., James, G. D., Paul, L. J., Marriott, P., Mackay, E., et al. (2019). New Zealand Fishes. A Field Guide to Common Species Caught by Bottom, Midwater, and Surface Fishing. New Zealand Aquatic Environment and Biodiversity Report 208, Prepared for Fisheries New Zealand. Wellington: Ministry of Primary Industries.

Moura, A. E., Sillero, N., and Rodrigues, A. (2012). Common dolphin (Delphinus delphis) habitat preferences using data from two platforms of opportunity. Acta. Oecol. 38, 24-32.

Nordøy, E. S., and Blix, A. S. (2009). Movements and dive behaviour of two leopard seals (Hydrurga leptonyx) off Queen Maud Land, Antarctica. Polar Biol. 32, 263-270. doi: 10.1007/s00300-008-0527-8

Ono, K. A., Steinbeiser, C. M., Coco, A. B., Sheehan, M. J., Beck, A. J., Dufault, M. N., et al. (2019). Detecting spiny dogfish in grey seal diets. Conserv. Genet. Resour. 11, 481-485. doi: 10.1007/s12686-018-1044-x

Peters, K. J., Ophelkeller, K., Bott, N. J., Deagle, B. E., Jarman, S. N., and Goldsworthy, S. D. (2015). Fine-scale diet of the Australian sea lion (Neophoca cinerea) using DNA-based analysis of faeces. Mar. Ecol. 36, 347-367. doi: $10.1111 /$ maec. 12145

Polis, G. A., Myers, C. A., and Holt, R. D. (1989). The ecology and evolution of intraguild predation: potential competitors that eat each other. Annu. Rev. Ecol. Syst. 20, 297-330. doi: 10.1146/annurev.es.20.110189. 001501

Purcell, M., Mackey, G., LaHood, E., Park, L., and Huber, H. (2004). Molecular methods for the genetic identification of salmonid prey from Pacific harbor seal (Phoca vitulina richardsi) scat. Fish. Bull. 102, 213-220.
Riedman, M. (1990). The Pinnipeds: Seals, Sea Lions, and Walruses, Vol. 12. London: University of California Press.

Robbins, J. R., Poncet, D., Evans, A. R., and Hocking, D. P. (2019). A rare observation of group prey processing in wild leopard seals (Hydrurga leptonyx). Polar Biol. 42, 1625-1630. doi: 10.1007/s00300-019-02542-z

Roberts, C. D., Stewart, A. L., and Struthers, C. D. (2015). The Fishes of New Zealand. Wellington: Te Papa Press.

Roberts, J., and Lalas, C. (2015). Diet of New Zealand sea lions (Phocarctos hookeri) at their southern breeding limits. Polar Biol. 38, 1483-1491.

Rogers, T. L. (2009). "Leopard seal Hydrurga leptonyx," in Encyclopedia of Marine Mammals, 2nd Edn, eds W. F. Perrin, B. Würsig, and J. G. M. Thewissen (San Diego, CA: Elsevier Academic Press), 673-674.

Rogers, T. L. (2018). "Leopard seal: Hydrurga leptonyx", in Encyclopedia of Marine Mammals, 3rd Edn, eds B. Würsig, J. G. M. Thewissen, and K. M. Kovacks (San Diego, CA: Elsevier Academic Press), 550-552.

Rosenblatt, A. E., Heithaus, M. R., Mather, M. E., Matich, P., Nifong, J. C., Ripple, W. J., et al. (2013). The roles of large top predators in coastal ecosystems: new insights from long term ecological research. Oceanography 26, 156-167. doi: 10.5670/oceanog.2013.59

Rounsevell, D., and Pemberton, D. (1994). The status and seasonal occurrence of leopard seals, Hydrurga leptonyx, in Tasmanian waters. Aust. Mammal. 17, 97-102. doi: 10.1071/am94010

Rowe, S. J. (2009). Conservation Services Programme Observer Report: 01 July 2004 to 30 June 2007. DOC Marine Conservation Services Series 1. Wellington: Department of Conservation.

Seersholm, F. V., Cole, T. L., Grealy, A., Rawlence, N. J., Greig, K., Knappe, M., et al. (2018). Subsistence practices, past biodiversity, and anthropogenic impacts revealed by New Zealand-wide ancient DNA survey. Proc. Natl. Acad. Sci. U.S.A. 115, 7771-7776. doi: 10.1073/pnas.18035 73115

Shaughnessy, P., Kirkwood, R., Cawthorn, M., Kemper, C., and Pemberton, D. (2003). "Pinnipeds, cetaceans and fisheries in Australia: a review of operational interactions," in Marine Mammals: Fisheries, Tourism and Management Issues, eds N. Gales, M. Hindell, and R. Kirkwood (Collingwood, VIC: CSIRO Publishing), 136-152.

Shepherd, L. D., and Campbell, M. (2021). Ancient DNA analysis of an archaeological assemblage of Chondrichthyes vertebrae from South Auckland. N. Z. J. Archaeol. Sci. 36, 1-6.

Simon, C., Frati, F., Beckenbach, A., Crespi, B., Liu, H., and Flook, P. (1994). Evolution, weighting, and phylogenetic utility of mitochondrial gene sequences and compilation of conserved polymerase chain reaction primers. Ann. Entomol. 87, 651-701. doi: 10.1093/aesa/87.6.651

Sinclair, E. H. (1994). Prey of juvenile northern elephant seals (Mirounga angustirostris) in the Southern California Bight. Mar. Mamm. Sci. 10, 230-239. doi: 10.1111/j.1748-7692.1994.tb00267.x

Siniff, D. B., and Stone, S. (1985). "The role of the leopard seal in the trophodynamics of the Antarctic marine ecosystem," in Antarctic Nutrient Cycles and Food Webs, eds W. R. Siegfried, P. R. Condy, and R. M. Laws (Berlin: Springer), $555-560$.

Stroud, R. K. (1979). Causes of death and pathological findings in marine mammals stranded along the Oregon coast. J. Wildl. Dis. 15, 91-97. doi: 10.7589/00903558-15.1.91

Valentini, A., Miquel, C., Nawaz, M. A., Bellemain, E., Coissac, E., Pompanon, F., et al. (2009). New perspectives in diet analysis based on DNA barcoding and parallel pyrosequencing: the trnL approach. Mol. Ecol. Resour. 9, 51-60. doi: 10.1111/j.1755-0998.2008.02352.x

Visser, I. N. (1999). Benthic foraging on stingrays by killer whales (Orcinus orca) in New Zealand waters. Mar. Mamm. Sci. 15, 220-227. doi: 10.1111/j.1748-7692. 1999.tb00793.x

Visser, I. N. (2000). Orca (Orcinus orca) in New Zealand waters. [Ph.D. thesis]. Auckland: University of Auckland.

Visser, I. N. (2005). First observations of feeding on thresher (Alopias vulpinus) and hammerhead (Sphyrna zygaena) sharks by killer whales (Orcinus orca) which specialise on elasmobranchs as prey. Aquat. Mamm. 31, 83-88. doi: 10.1578/AM.31.1.2005.83

Visser, I. N., Berghan, J., van Meurs, R., and Fertl, D. (2000). Killer whale (Orcinus orca) predation on a shortfin mako shark (Isurus oxyrinchus) in New Zealand waters. Aquat. Mamm. 26, 229-231. 
Warneke, R. M. (1995). "Family phocidae," in Mammals of Victoria: Distribution, Ecology and Conservation, ed. P. W. Menkhorst (Melbourne: Oxford University Press), 251-256.

Weigmann, S. (2016). Annotated checklist of the living sharks, batoids and chimaeras (Chondrichthyes) of the world, with a focus on biogeographical diversity. J. Fish Biol. 88, 837-1037. doi: 10.1111/jfb.12874

Wilson, S., Anderson, E. M., Wilson, A. S. G., Bertram, D. F., and Arcese, P. (2013). Citizen science reveals an extensive shift in the winter distribution of migratory western grebes. PLoS One 8:e65408. doi: 10.1371/journal.pone. 0065408

Conflict of Interest: The authors declare that the research was conducted in the absence of any commercial or financial relationships that could be construed as a potential conflict of interest.
Publisher's Note: All claims expressed in this article are solely those of the authors and do not necessarily represent those of their affiliated organizations, or those of the publisher, the editors and the reviewers. Any product that may be evaluated in this article, or claim that may be made by its manufacturer, is not guaranteed or endorsed by the publisher.

Copyright $\odot 2021$ van der Linde, Visser, Bout, Lalas, Shepherd, Hocking, Finucci, Fyfe and Pinkerton. This is an open-access article distributed under the terms of the Creative Commons Attribution License (CC BY). The use, distribution or reproduction in other forums is permitted, provided the original author $(s)$ and the copyright owner(s) are credited and that the original publication in this journal is cited, in accordance with accepted academic practice. No use, distribution or reproduction is permitted which does not comply with these terms. 